\title{
STUDIES OF CALCIUM AND PHOSPHORUS METABOLISM
}

\section{ON Temporary Fluctuations in the Level of Calcium and Inorganic Phosphorus in Blood Serum of NORMAL INDIVIDUALS}

\author{
RAY F. FARQUHARSON AND DOROTHY M. TIBBETTS
}

(From the Medical Clinic of the Massachusetts General Hospital, Boston)

(Received for publication November 26, 1930)

In the investigation of various problems of calcium and phosphorus metabolism, it has been found that great changes in the volume and direction of the calcium and phosphorus stream may occur without any notable difference in the serum levels of these elements. In hyperthyroidism the calcium excretion in the urine is relatively huge and there are large negative balances of calcium and phosphorus, yet the serum calcium and serum phosphorus ${ }^{1}$ remain within normal limits (1). Moreover, there is no appreciable change in the serum levels of healthy people when, by changing the calcium intake, a positive balance is shifted to a negative one or vice versa.

Yet the actual and relative amounts of calcium and phosphorus in the serum is of the utmost importance in certain abnormal conditions. MacCallum and Voegtlin (2) described the low blood and tissue calcium associated with tetany after removal of the parathyroids. Greenwald (3) later demonstrated the associated rise in serum phosphorus and since that time the high phosphorus, low calcium of the serum in many types of tetany has come to be recognized. Marriot and Howland (4), DeWesselow (5) and others have found a similar relationship of the serum values in terminal nephritis. On injection of large amounts of inorganic phosphate into dogs Binger (6) produced tetany with a low serum calcium and high serum phosphorus. Similar results have been found to follow injection or ingestion of very large quantities of phosphate by numerous investigators $(7,8,9)$. The

${ }^{1}$ Throughout this paper the term "serum phosphorus" is used in referring to serum inorganic phosphorus. 
feeding of much smaller amounts of phosphate to rachitic rats has been found to produce tetany with the typical blood changes by Karelitz and Shohl (10). That in rachitic animals even the high phosphorus metabolism of fasting may have similar effects has been shown by Cavins, (11), Wilder, (12), and Shohl and Brown (13). The ingestion of sodium oxalate in dogs was found to result in a low blood calcium, high phosphorus, and tetany (14).

In states of hyperparathyroidism, on the other hand, a high serum calcium is well known to be associated with a low serum phosphorus. This has been discussed in other papers $(15,16)$.

It is quite clear, therefore, that gross changes in the serum phosphorus value in many conditions are associated with equally marked variation of the serum calcium in the opposite direction. That the level of serum calcium is also affected by the protein content of the serum was shown by Salvesen and Linder (17). Hastings, Murray and Sendroy (18) showed that there was a linear relationship between the protein content of serum or transudate and the calcium level. Their data, taken from human sera and transudates as drawn from the body, indicate that 0.014 millimol of calcium are bound per gram of protein at the $\mathrm{pH}$ value of the blood. Peters and Eiserson (19) also found in a group of cases, mostly nephritics, that the concentration of calcium in the serum varies directly with the concentration of protein and inversely with the concentration of inorganic phosphorus.

Other investigators have described temporary fluctuations in either serum calcium or phosphorus of normal individuals in response to various factors. Thus, Stewart and Haldane (20) found that an increase of from 1.5 to $2 \mathrm{mgm}$. in serum calcium might occur after ingestion of 30 grams $\mathrm{CaCl}_{2}$, after forced breathing for 90 minutes, and after breathing 6 to 7 per cent $\mathrm{CO}_{2}$ for 90 minutes; and a decrease of about $2 \mathrm{mgm}$. after ingestion of 60 grams $\mathrm{NaHCO}_{3}$. Although values for serum phosphorus were not given in this paper it was reported separately (21) that forced breathing for 90 minutes resulted in every instance in a fall in serum inorganic phosphorus to below 1.25 mgm. Salvesen, Hastings, and McIntosh (22) found that intravenous injection of $\mathrm{CaCl}_{2}$ resulted in a moderate rise in serum phosphorus as well as a temporary rise in serum calcium.

The object of our investigation was to determine the extent of 
temporary variation in the serum levels of calcium and phosphorus in normal adults and to what degree the inverse relationship noted above would prevail when changes in one or another component could be induced at will. Accordingly, the serum levels were determined at various times of the day in subjects on ordinary diets and after ingestion of food rich respectively in carbohydrates, fat, and protein, as well as when insulin was given preceding a carbohydrate meal. The effect of ingestion of large amounts of salts of calcium and phosphorus was also followed.

\section{METHODS}

Venous blood was taken from the arm into a clean syringe, previously washed with liquid paraffin, care being taken to avoid any unnecessary manipulation and to prevent hemolysis. As soon as clotting was complete the serum was separated by centrifugalization, and removed. In some cases the $\mathrm{CO}_{2}$ content or capacity of the plasma was determined by the Van Slyke method, the blood having been taken under oil and coagulation prevented by the use of heparin. For these determinations we are indebted to Dr. A. V. Bock. Serum protein was determined by macro Kjeldahl, serum phosphorus by the method of Fiske and Subbarow (23), and serum calcium by Fiske's (24) method. The latter method has proven most satisfactory under all conditions. Determinations were done in duplicate, usually with identical results, the variation seldom being greater than 2 per cent.

In all cases, blood was first taken during fasting and then at varying intervals after different types of meals or after ingestion of calcium salts or phosphates.

\section{EXPERIMENTS AND RESULTS}

\section{The level during fasting}

It was important to find whether the basal fasting level would be appreciably affected by changes in type of diet or by ingestion of excess acid, alkali, or phosphate as well as to note any temporary change occurring immediately after such ingestion. Also, it was interesting to observe the relative constancy of the fasting levels of the serum calcium and phosphorus over comparatively long periods. In table 1 are presented data for such observations on two healthy individuals. 
TABLE 1

Serum values (fasting) in two healthy subjects

\begin{tabular}{|c|c|c|c|c|c|c|}
\hline Date & Calcium & $\begin{array}{l}\text { Phos- } \\
\text { phorus }\end{array}$ & Protein & $\begin{array}{c}\text { Plasma } \\
\mathrm{CO}_{2} \\
\text { content }\end{array}$ & $\begin{array}{l}\text { Total } \\
\text { fixed } \\
\text {-base }\end{array}$ & Remarks \\
\hline \multicolumn{7}{|c|}{ Subject R. F. F. } \\
\hline 1928 & $\begin{array}{c}\text { mgm. } \\
\text { per } \\
100 c c .\end{array}$ & $\begin{array}{c}\text { mgm. } \\
\text { per } \\
100 c c .\end{array}$ & per cent & $\begin{array}{l}\text { volumes } \\
\text { per cent }\end{array}$ & $\begin{array}{c}\text { m.Eq. } \\
\text { per liter }\end{array}$ & \\
\hline January 27 & 9.6 & 3.4 & 6.9 & 70.7 & 148 & Ordinary diet \\
\hline February 2 & 9.7 & 4.2 & & 71.2 & 152 & $\begin{array}{l}6 \text { grams } \mathrm{NaHCO}_{3} \text { taken daily, } \\
\text { January } 27 \text { to February } 2\end{array}$ \\
\hline February 6 & 9.6 & 3.6 & 6.3 & 69.5 & & $\begin{array}{l}12 \text { grams } \mathrm{NaHCO}_{3}+12 \text { grams } \\
\text { sodium citrate February } 2-6\end{array}$ \\
\hline February 9 & 9.1 & 3.2 & 6.4 & 71.8 & 168 & $\begin{array}{l}52 \text { grams } \mathrm{NaHCO}_{3} \text { on February } 7 \\
56 \text { grams } \mathrm{NaHCO}_{3} \text { on February } 8\end{array}$ \\
\hline February 11 & 10.0 & 3.7 & & 58.6 & & $\begin{array}{r}4 \text { grams } \mathrm{NH}_{4} \mathrm{Cl} \text { on February } 9 \\
12 \text { grams } \mathrm{NH}_{4} \mathrm{Cl} \text { on February } 10\end{array}$ \\
\hline February 13 & 10.0 & 3.4 & 8.0 & $29.1 *$ & 162 & $\begin{array}{l}12 \text { grams } \mathrm{NH}_{4} \mathrm{Cl} \text { on February } 11 \\
15 \text { grams } \mathrm{NH}_{4} \mathrm{Cl} \text { on February } 12\end{array}$ \\
\hline February 20 & 9.6 & 3.9 & & & & Ordinary diet \\
\hline February 27 & 10.1 & 3.2 & & & & Ordinary diet \\
\hline April 10 & 10.1 & 2.5 & 5.9 & & & Low calcium diet April 5-14 \\
\hline April 19 & 9.6 & 3.2 & 6.4 & & & High protein diet April 14-27 \\
\hline April 23 & 10.1 & 3.0 & & 63.8 & & \\
\hline April 26 & 10.2 & 3.6 & 7.1 & 61.7 & & \\
\hline June 16 & 9.6 & 3.8 & & & & High protein diet June $11-16$ \\
\hline June 19 & 9.5 & 3.4 & 6.6 & & & Ordinary diet \\
\hline June 22 & 9.6 & 3.6 & & & & Ordinary diet \\
\hline June 26 & 9.6 & 3.2 & 6.6 & & & Ordinary diet \\
\hline \multicolumn{7}{|l|}{1930} \\
\hline May 26 & 10.0 & 3.1 & & & & \\
\hline \multicolumn{7}{|c|}{ Subject D. M. T. } \\
\hline 1928 & & & \multirow{8}{*}{6.9} & & & \multirow{8}{*}{ Ordinary diet throughout } \\
\hline February 27 & 10.1 & 3.3 & & & & \\
\hline March 5 & 9.8 & 3.6 & & & & \\
\hline June 27 & 9.2 & 3.3 & & & & \\
\hline November 24 & 9.5 & 3.7 & & & & \\
\hline December 10 & 10.0 & 3.5 & & & & \\
\hline 1930 & & & & & & \\
\hline May 27 & 9.6 & 3.2 & & & & \\
\hline
\end{tabular}

* Total $\mathrm{CO}_{2}$ oxygenated whole blood. 
In the case of R. F. F. the fasting serum calcium was remarkably constant at about 9.6 to $10.0 \mathrm{mgm}$. per $100 \mathrm{cc}$. Under the influence of ingestion of very large amounts of alkali, it fell to $9.1 \mathrm{mgm}$., a result similar, although not as great, as that obtained by Stewart and Haldane (20). Apart from this single lower value all other determinations, including those taken during periods on very high protein diets and on ingestion of large amounts of $\mathrm{NH}_{4} \mathrm{Cl}$, lay between 9.5 and $10.2 \mathrm{mgm}$. Variation in the serum phosphorus level was a little greater than that of calcium, ranging as it did from 2.5 to $4.2 \mathrm{mgm}$. In eight instances, when the fasting serum calcium was 9.6 or $9.7 \mathrm{mgm}$., the phosphorus varied between 4.2 and $3.2 \mathrm{mgm}$.; when the serum calcium was 10.0 to 10.2 serum phosphorus values ranged from 2.5 to $3.7 \mathrm{mgm}$. The effect of high phosphorus intake in the form of a very high protein diet (200 grams protein daily) had no appreciable affect on the fasting values nor did the ingestion of large doses of $\mathrm{NH}_{4} \mathrm{Cl}$. The serum protein varied from 5.9 to 8.0 per cent.

In subject D. M. T. a smaller number of determinations showed a slightly greater variation in the calcium and smaller variation in the phosphorus level.

That ingestion of large amounts of inorganic phosphate in patients on a low calcium diet produced no appreciable effect on the fasting serum calcium and phosphorus levels has been mentioned in another paper (25). After several weeks on a low calcium diet, also, as described elsewhere (26), ingestion of large amounts of $\mathrm{NH}_{4} \mathrm{Cl}$ was associated with slightly decreased levels for calcium and phosphorus in some cases, and ingestion of $\mathrm{NaHCO}_{3}$ with increased levels for serum calcium. In all experiments, however, on ingestion of acid or alkali on high or low calcium diets, the total range of variation of many determinations for any given individual was never greater than 1 mgm. calcium except in one instance. In patient D. A. (Case II, period XV), described elsewhere (26), the ingestion of large amounts of $\mathrm{NH}_{4} \mathrm{Cl}$ after the subject had been on a low calcium diet for several weeks, resulted in a fall of slightly more than $1 \mathrm{mgm}$. in serum calcium.

\section{Absolute rest and mild exercise}

In one instance, it was found that there was a definite slight increase in serum calcium and protein and fall in serum phosphorus in blood 
taken from a fasting, healthy subject after lying at complete rest for one and one-quarter hours. This was repeated in a number of healthy individuals; but no material change in levels of calcium or phosphorus was found, although the serum protein did change considerably. The results are presented in table 2 .

TABLE 2

Effect of absolute rest and mild exercise during fasting

\begin{tabular}{|c|c|c|c|c|c|}
\hline Subject & Date & Calcium & $\begin{array}{l}\text { Phos- } \\
\text { phorus }\end{array}$ & Protein & Remarks \\
\hline . & 1928 & $\begin{array}{l}\text { mgm. } \\
\text { per } \\
100 \mathrm{cc} .\end{array}$ & $\begin{array}{l}\text { mgm. } \\
\text { per } \\
100 c c .\end{array}$ & per cent & \\
\hline $\mathrm{D} F$ & $A=$ - 10 & 9.6 & 3.2 & 6.4 & After walking $\frac{1}{2}$ mile \\
\hline R. F. F. & April 19 & 10.1 & 2.8 & 7.6 & After $1 \frac{1}{4}$ hours complete rest \\
\hline $\mathrm{F}$ & 28 ממוי & 9.5 & 3.8 & 5.9 & At rest, before rising \\
\hline C. F. & June 28 & 9.5 & 3.5 & 6.6 & After working one hour \\
\hline \multirow{2}{*}{ F. A. } & \multirow{2}{*}{ June 28} & 9.8 & 3.6 & \multirow{2}{*}{$\begin{array}{l}7.1 \\
5.9^{*}\end{array}$} & After working one hour \\
\hline & & 9.6 & 3.6 & & After lying down one hour \\
\hline \multirow{3}{*}{ D. M. T. } & November 24 & $\begin{array}{l}9.5 \\
9.7\end{array}$ & 3.7 & & $\begin{array}{l}\text { After working three hours } \\
\text { After lying down one hour }\end{array}$ \\
\hline & & 10.0 & 3.5 & & After working three hours \\
\hline & December 10 & 10.0 & 3.2 & & After lying down one hour \\
\hline \multirow{3}{*}{ G. P. R. } & November 24 & $\begin{array}{l}10.4 \\
10.4\end{array}$ & 4.5 & & $\begin{array}{l}\text { Before rising } \\
\text { Moving about for one hour }\end{array}$ \\
\hline & \multirow{2}{*}{ December 10} & 10.2 & 3.9 & & Before rising \\
\hline & & 10.4 & 3.5 & & Moving about for one hour \\
\hline
\end{tabular}

* Some hemolysis.

Fluctuations in serum calcium during the day when on ordinary diet

The serum levels of two healthy subjects were determined at different times during a day when an ordinary diet was taken and ordinary work done. Results are presented in table 3 . In subject R. F. F. the calcium remained constant at 9.9 to $10.0 \mathrm{mgm}$., while the phosphorus varied between 3.0 to $3.8 \mathrm{mgm}$. In D. M. T. the serum 
calcium varied between 9.4 and $10.4 \mathrm{mgm}$., a range as great as that of the fasting values over many months; and the serum phosphorus between 3.1 and $3.8 \mathrm{mgm}$. It is notable that the highest value for calcium was obtained at the same time as the highest value for phosphorus.

TABLE 3

Serum values during the day on ordinary diet

\begin{tabular}{|c|c|c|c|c|c|c|}
\hline Subject & Date & Time & Calcium & $\begin{array}{c}\text { Phos- } \\
\text { phorus }\end{array}$ & Protein & Remarks \\
\hline \multirow{8}{*}{ R.F.F. } & 1930 & & $\underset{\text { per } 100 \text { cc. }}{\text { mgm. }}$ & $\begin{array}{c}\text { mgm. } \\
\text { per } \\
100 \text { cc. }\end{array}$ & per cent & \multirow{5}{*}{ Eggs, toast, and coffee } \\
\hline & \multirow{7}{*}{ May 26} & 9:00 & 10.0 & 3.1 & 6.8 & \\
\hline & & $9: 30$ & Breakfast & & & \\
\hline & & $11: 30$ & 10.0 & 3.0 & 7.5 & \\
\hline & & $12: 45$ & 9.9 & 3.2 & 7.5 & \\
\hline & & $1: 00$ & Lunch & & & \multirow{3}{*}{$\begin{array}{l}\text { Ham, carrots, } \\
\text { custard }\end{array}$} \\
\hline & & $2: 15$ & 10.0 & 3.8 & 7.2 & \\
\hline & & $5: 00$ & 10.0 & 3.8 & 7.2 & \\
\hline \multirow{6}{*}{ D. M. T. } & \multirow{6}{*}{ May 26} & $9: 00$ & 9.6 & 3.2 & 7.8 & \multirow{6}{*}{$\begin{array}{l}\text { Toast, marmalade, coffee } \\
\text { Ham, potatoes, carrots, } \\
\text { custard }\end{array}$} \\
\hline & & $9: 30$ & Breakfast & & & \\
\hline & & $11: 30$ & 9.7 & 3.1 & 8.0 & \\
\hline & & $12: 15$ & Lunch & & & \\
\hline & & $1: 30$ & 9.4 & 3.7 & 7.8 & \\
\hline & & $4: 45$ & 10.4 & 3.8 & 8.3 & \\
\hline
\end{tabular}

Ingestion of carbohydrate, or carbohydrate with administration of insulin

It has been clearly shown that the administration of insulin or the ingestion of large amounts of carbohydrate with or without insulin results in a prompt fall in the serum inorganic phosphorus $(27,28,29)$. It was, therefore, interesting to find to what extent the serum calcium would vary when rapid changes in serum phosphorus were induced in this way. Accordingly, large amounts of carbohydrate in the form of ordinary foods or 100 grams of glucose were given to a number of healthy subjects and to some patients, including a case of tetany with high serum phosphorus. The changes in serum phosphorus, calcium, and blood sugar were followed for several hours. Results are given in table 4. 
TABLE 4

Effect of ingestion of large amounts of carbohydrates

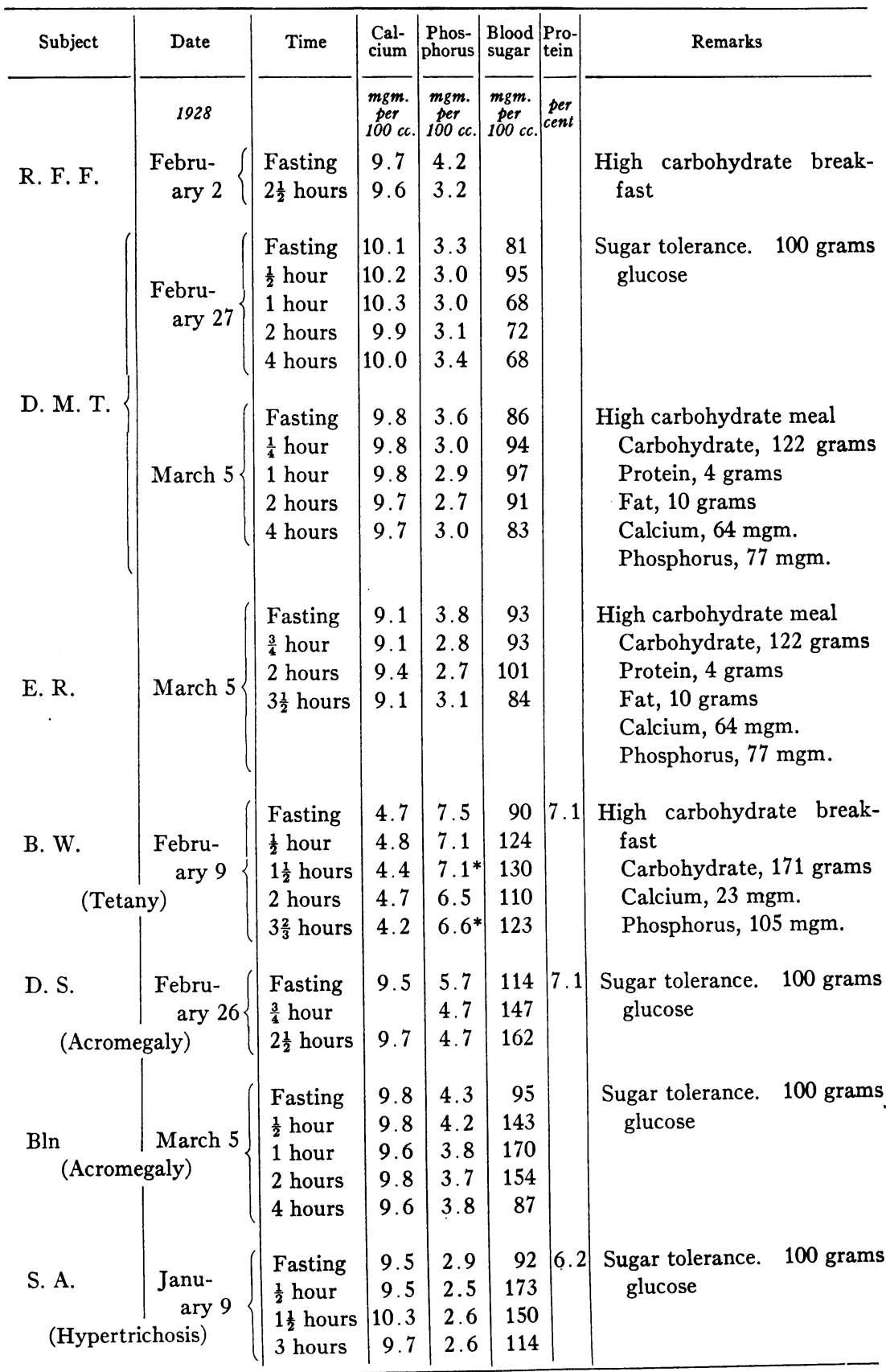

* Some hemolysis. 
The effects of ingestion of large amounts of carbohydrate immediately after the administration of a large dose of insulin in three normal subjects are shown by data collected in table 5 .

TABLE 5

Effect of ingestion of large amounts of carbohydrate and administration of insulin

\begin{tabular}{|c|c|c|c|c|c|c|c|}
\hline Subject & Date & Time & 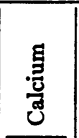 & 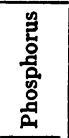 & 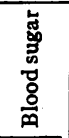 & 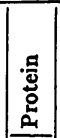 & Remarks \\
\hline \multirow{11}{*}{ R. F. F. } & 1928 & & $\begin{array}{c}\text { mgm. } \\
\text { per } \\
100 \text { cc. }\end{array}$ & $\begin{array}{c}\text { mgm. } \\
\text { per } \\
100 \text { ce. }\end{array}$ & $\begin{array}{c}\text { mgm. } \\
\text { per } \\
100 \mathrm{cc} .\end{array}$ & $\begin{array}{c}\text { per } \\
\text { cent }\end{array}$ & \multirow{11}{*}{$\begin{array}{l}30 \text { units insulin } \\
\text { Breakfast } \\
\text { Carbohydrate, } 126 \text { grams } \\
\text { Protein, } 8 \text { grams } \\
\text { Fat, } 3 \text { grams } \\
\text { Calcium, } 67 \text { mgm. } \\
\text { Phosphorus, } 170 \text { mgm. }\end{array}$} \\
\hline & \multirow{10}{*}{ June 26} & Fasting & 9.6 & 3.2 & 98 & 6.6 & \\
\hline & & 50 minutes & 9.4 & 2.4 & 105 & 6.9 & \\
\hline & & $1 \frac{1}{2}$ hours & 10.0 & 2.1 & 64 & 6.7 & \\
\hline & & 3 hours & $\mid 10.4$ & 2.1 & 46 & 6.8 & \\
\hline & & \multicolumn{5}{|c|}{ 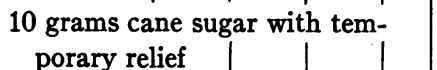 } & \\
\hline & & 4 hours & 19.5 & 2.4 & 46 & 7.1 & \\
\hline & & 30 grams g & ucose & & & & \\
\hline & & $5 \frac{1}{4}$ hours & $\mid 9.6$ & 2.9 & 46 & $\mid 7.2$ & \\
\hline & & 30 grams gl & acose $p$ & lus 25 & grams & & \\
\hline & & 8 hours & 9.7 & 4.2 & 91 & & \\
\hline \multirow{5}{*}{ D. M. T. } & \multirow{5}{*}{ June 27} & Fasting & 9.2 & 3.3 & 84 & 6.9 & \multirow{5}{*}{$\begin{array}{l}20 \text { units insulin } \\
\text { Breakfast } \\
\text { Carbohydrate, } 109 \text { grams } \\
\text { Protein, } 8 \text { grams } \\
\text { Fat, } 7 \text { grams } \\
\text { Calcium, } 70 \text { mgm. } \\
\text { Phosphorus, } 118 \text { mgm. }\end{array}$} \\
\hline & & $\frac{1}{2}$ hour & 9.6 & 2.8 & 77 & 7.4 & \\
\hline & & 2 hours & 9.6 & 2.5 & 73 & 6.8 & \\
\hline & & $\begin{array}{l}3 \frac{1}{2} \text { hours } \\
\text { Lunch }\end{array}$ & 9.8 & 3.0 & 41 & 6.1 & \\
\hline & & $7 \frac{1}{2}$ hours & 9.2 & 3.3 & 105 & 6.6 & \\
\hline \multirow{5}{*}{ E. R. } & \multirow{5}{*}{ June 27} & Fasting & 9.3 & 4.3 & 93 & 6.2 & \multirow{5}{*}{$\begin{array}{l}20 \text { units insulin } \\
\text { Breakfast } \\
\text { Carbohydrate, } 109 \text { grams } \\
\text { Protein, } 8 \text { grams } \\
\text { Fat, } 7 \text { grams } \\
\text { Calcium, } 70 \text { mgm. } \\
\text { Phosphorus, } 118 \text { mgm. }\end{array}$} \\
\hline & & $\frac{1}{2}$ hour & 9.5 & 3.5 & 104 & 6.1 & \\
\hline & & 2 hours & 9.4 & 3.7 & 53 & 6.1 & \\
\hline & & $\begin{array}{l}3 \frac{1}{2} \text { hours } \\
\text { Lunch }\end{array}$ & 9.3 & 3.6 & 60 & 6.1 & \\
\hline & & $7 \frac{1}{2}$ hours & 9.0 & 3.6 & 200 & & \\
\hline
\end{tabular}

The results, in so far as the serum calcium and phosphorus levels are concerned, were essentially the same for ingestion of carbohydrate alone as when it followed the administration of insulin. In the latter cases, however, the blood sugar fell to reaction levels. 
In all subjects there was an early fall in serum phosphorus levels, averaging in eleven instances $0.8 \mathrm{mgm}$. and varying from slightly less than $0.5 \mathrm{mgm}$. to slightly more than $1.0 \mathrm{mgm}$. The initial height of the serum phosphorus seemed to have no influence on the magnitude of the change, nor did there seem to be any definite relation between the extent of the decrease in serum phosphorus and the change in the blood sugar level. When the phosphorus fell there was some tendency for the serum calcium to rise but this was by no means constant nor did the increase in serum calcium vary directly with the extent of decrease in serum phosphorus. With a maximum fall of about 1 mgm. in serum phosphorus the serum calcium remained essentially constant in R. F. F., February 2; D. M. T., March 5; E. R., March 5; and in DS (acromegaly). In the case B. W. (tetany), when the phosphorus fell from 7.5 to 6.5 the calcium remained essentially constant until the last determination, when, without further appreciable change in serum phosphorus it fell from 4.7 to 4.2. On the other hand, in R. F. F., June 26, the serum calcium rose from 9.6 to 10.4 mgm., while the phosphorus fell from 3.2 to 2.1 . In eight hours, however, when the serum calcium had returned to 9.7 the serum phosphorus had risen to $4.2,1 \mathrm{mgm}$. higher than the fasting level. In D. M. T., June 27, when the serum phosphorus was decreased by $0.8 \mathrm{mgm}$. the calcium rose from 9.2 to 9.6 , reaching 9.8 one and one-half hours later when phosphorus had returned nearly to normal. In the case of hypertrichosis, the maximum rise in calcium was $0.9 \mathrm{mgm}$. and maximum fall in phosphorus $0.4 \mathrm{mgm}$. The serum calcium was essentially unchanged in at least six of the eleven cases, and only in three cases was there a variation of $0.5 \mathrm{mgm}$. or more, the greatest increase above fasting level being $1 \mathrm{mgm}$. in R. F. F. after carbohydrate and insulin. In the cases in which serum protein was determined there seemed to be no constant relation between the temporary variations in protein and those of calcium.

Thus, our results are in agreement with the well established fact that the ingestion of large amounts of carbohydrate with or without administration of insulin is constantly followed by a definite fall in serum phosphorus. They show on the whole little associated change in serum calcium, the magnitude of which was no greater than that found to occur on ordinary diet or after ingestion of other types of food 
as described below. Similar values for serum calcium in dogs, after administration of insulin, were obtained by Briggs, Koechig, Doisy and Weber (30). Brougher, however, reported tremendous changes in blood calcium of rabbits (rising even to more than $20 \mathrm{mgm}$.) following injection of insulin (31). Davies, Dickens, and Dodds (32) found increases of from 2 to $4 \mathrm{mgm}$. in serum calcium of rabbits in hypoglycemic convulsions. Recently, Ellsworth (33) has reported increases in serum calcium in man similar to those that occurred in some of our cases. The maximum change in calcium did not occur always in those cases with the greatest fall in phosphorus, nor was the reciprocal inverse relationship persistent in the last determinations of a given experiment. Yet in his cases there was a more constant rise in serum calcium than in ours.

\section{Ingestion of large amounts of protein and fat}

Data showing the effect of ingestion of large amounts of protein and fat are presented in table 6 .

When 127 grams of fat were taken, much of it in the form of cream, there followed an increase of calcium from 9.6 to $10.8 \mathrm{mgm}$. and a fall in phosphorus from 3.9 to $3.2 \mathrm{mgm}$. A week later the effect of 100 grams of olive oil was observed; the serum phosphorus remained constant but serum calcium increased by $0.9 \mathrm{mgm}$. in 4 hours. Similar experiments on ingestion of large amounts of protein, when the subject took 200 grams of protein daily for several days, showed in one instance a distinct rise in calcium from fasting value of $9.6 \mathrm{mgm}$. to $11.4 \mathrm{mgm}$. a few hours after breakfast, associated with a slight increase in serum phosphorus, but no material difference in serum protein. In this instance $\mathrm{NaHCO}_{3}$ was added to neutralize the acid effect of ingested protein. When the experiment was subsequently repeated, leaving out the $\mathrm{NaHCO}_{3}$, the serum calcium remained stationary and serum phosphorus rose slightly. On each occasion the subject was carrying on with his ordinary work.

Data showing the effect of ingestion of single doses of phosphate and of calcium lactate are presented in table 7 . The phosphate caused purgation, which persisted for several hours. The serum phosphorus, however, rose from 3.5 to $5.0 \mathrm{mgm}$., without an appreciable change in the serum calcium level. A similar rise in serum phosphorus after 


\section{NORMAL FLUCTUATIONS IN BLOOD CALCIUM AND PHOSPHORUS}

ingestion of large amounts of phosphate without any associated change in the serum calcium level has been described by Schulz (34). The ingestion of calcium lactate was followed by an increase in serum

TABLE 6

Effect of ingestion of large amounts of protein and of fat

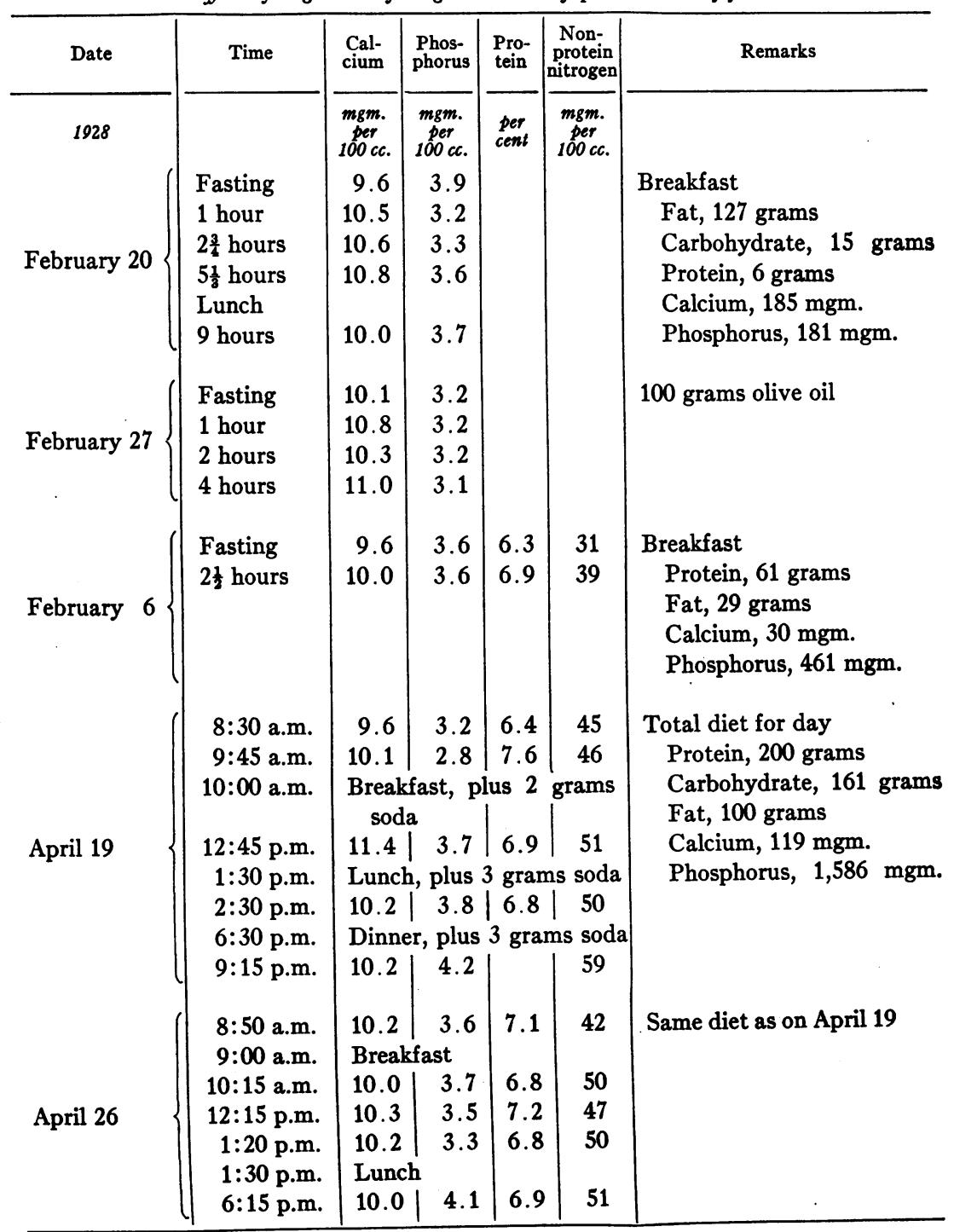


calcium from 9.6 to $11.0 \mathrm{mgm}$. but the inorganic phosphorus remained relatively constant.

TABLE 7

Effect of ingestion of sodium phosphate and of calcium lactate

\begin{tabular}{|c|c|c|c|c|}
\hline Date & Time & Calcium & Phosphorus & Remarks \\
\hline 1928 & & per 100 ce. & $\underset{\text { per } 100 \text { cc. }}{m g m .}$ & \\
\hline June 19 & $\begin{array}{l}\text { Fasting } \\
1 \text { hour } \\
3 \frac{1}{2} \text { hours } \\
5 \text { hours }\end{array}$ & $\begin{array}{l}9.5 \\
9.4 \\
9.5 \\
9.2\end{array}$ & $\begin{array}{l}3.5 \\
5.0 \\
4.9 \\
5.0\end{array}$ & $\begin{array}{l}3 \text { grams phosphorus in form of } \\
\text { equimolecular solution of } \\
\mathrm{NaH}_{2} \mathrm{PO}_{4} \text { and } \mathrm{Na}_{2} \mathrm{HPO}_{4} \text {. Pur- } \\
\text { gation followed in about one hour }\end{array}$ \\
\hline June 22 & $\begin{array}{l}\text { Fasting } \\
2 \text { hours } \\
3 \text { hours } \\
5 \text { hours } \\
\text { Lunch } \\
9 \text { hours }\end{array}$ & $\begin{array}{r}9.6 \\
11.0 \\
10.5 \\
10.5 \\
\\
10.3\end{array}$ & $\begin{array}{l}3.6 \\
3.6 \\
3.6 \\
4.2^{*} \\
\\
3.8\end{array}$ & $\begin{array}{l}10 \text { grams calcium lactate }=1.3 \\
\text { grams calcium }\end{array}$ \\
\hline
\end{tabular}

* Some hemolysis.

\section{COMMENT}

It is seen that there may be greater changes in the serum calcium and phosphorus within a few hours after meals of ordinary foodstuffs than occur in the fasting levels over periods of many months. The fasting serum calcium, however, and to a lesser extent the serum phosphorus, remains remarkably constant in spite of great changes in diet and in the intake of calcium and phosphate.

Although the inverse relationship between the levels of calcium and phosphorus of the serum seems to hold in some instances during temporary fluctuations, it is quite clear that in many cases the calcium was constant while the phosphorus level changed, in others the phosphorus remained constant during changes in calcium, and in some instances both rose or fell together. Concomitant variation in the serum protein was not great enough to overshadow a specific effect of variation in phosphorus on the calcium level or vice versa, nor were temporary fluctuations in protein always paralleled by corresponding changes in serum calcium when the serum phosphorus remained constant. 
These observations do not affect the truth of the statement that the serum calcium level varies directly with the protein content and inversely with the concentration of inorganic phosphorus; for the changes described occurred during periods of flux, were of short duration and did not represent equilibrium values. Their magnitude, moreover was much less than that of corresponding changes in terminal nephritis, in cases with very low serum protein, and in tetany. It is possible, however, that they represent influences of other factors that are difficult of control, factors that might affect the level of either serum calcium or serum phosphorus independently.

\section{SUMMARY}

Fasting values for serum calcium and phosphorus of healthy individuals show only slight variations over long periods, whereas greater changes may occur within a few hours after ingestion of ordinary foodstuffs. It is interesting how small are the variations.

In such temporary fluctuations the serum calcium does not always vary inversely with the serum inorganic phosphorus, although there is some tendency for it to do so.

Temporary changes in serum protein are not always associated with corresponding variations in the serum calcium.

Ingestion of large amounts of carbohydrate or carbohydrate after administration of insulin is constantly followed by a fall in the serum inorganic phosphorus and sometimes but not always by a slight increase in serum calcium.

The magnitude of the diurnal variations in the serum calcium and phosphorus was small when compared with the great changes found in states of tetany and terminal nephritis.

\section{BIBLIOGRAPHY}

1. Aub, J. C., Bauer, W., Heath C., and Ropes, M., J. Clin. Invest., 1929, vii, 97. Studies of Calcium and Phosphorus Metabolism. III. The Effects of the Thyroid Hormone and Thyroid Disease.

2. MacCallum, W. G., and Voegtlin, C., J. Exp. Med., 1909, xi, 118. On the Relation of Tetany to the Parathyroid Glands and to Calcium Metabolism.

3. Greenwald, I., J. Biol. Chem., 1913, xiv, 369. On the Phosphorus Content of the Blood of Normal and Parathyroidectomized Dogs. 
4. Marriott, W. M., and Howland, John, Arch. Int. Med., 1916, xviii, 708. Phosphate Retention as a Factor in the Production of Acidosis in Nephritis.

5. DeWesselow, O. L. V., Quart. J. Med., 1922-23, xvi, 341. On the Phosphorus and Calcium of the Blood in Renal Disease.

6. Binger, C., J. Pharm. and Exp. Therap., 1917, x, 105. Toxicity of Phosphates in Relation to Blood Calcium and Tetany.

7. Tisdall, F. F., J. Biol. Chem., 1922, liv, 35. The Influence of the Sodium Ion in the Production of Tetany.

8. Salvesen, H. A., Hastings, A. B., and McIntosh, J. F., J. Biol. Chem., 1924, $\mathrm{lx}, 311$. Blood Changes and Clinical Symptoms Following Oral Administration of Phosphates.

9. Gates, F. L., and Grant, J. H. B., J. Exp. Med., 1927, xlv, 125. Experimental Observations on Irradiated, Normal, and Partially Parathyroidectomized Rabbits. II. The Effects of Injections of Calcium Chloride or of Disodium Hydrogen Phosphate.

10. Karelitz, S., and Shohl, A. T., J. Biol. Chem., 1927, lxxiii, 665. Rickets in Rats. II. The Effect of Phosphorus Added to the Diet of Ricketic Rats.

11. Cavins, A. W., J. Biol. Chem., 1924, lix, 237. The Effect of Fasting (and Refeeding) on the Calcium and Inorganic Phosphorus in Blood Serum of Normal and Rachitic Rats.

12. Wilder, T. S., J. Biol. Chem., 1929, lxxxi, 65. The Tetany of Fasting in Experimental Rickets.

13. Shohl, A. T., and Brown, H. B., J. Biol. Chem., 1929, lxxxiv, 501. Rickets in Rats. X. Fasting Tetany and Phosphate Tetany.

14. Gross, E. G., J. Biol. Chem., 1923, lv, 729. Inorganic Salt Metabolism. II. Inorganic Ion Ratio After Administration of Oxalates and Citrates.

15. Albright, F., Bauer, W., Ropes, M., and Aub, J. C., J. Clin. Invest., 1929, vii, 139. Studies of Calcium and Phosphorus Metabolism. IV. The Effect of the Parathyroid Hormone.

16. Bauer, W., Albright, F., and Aub, J. C., J. Clin. Invest., 1930, viii, 229. A Case of Osteitis Fibrosa Cystica (Osteomalacia) with Evidence of Hyperactivity of the Parathyroid Bodies. Metabolic Study II.

17. Salvesen, H. A., and Linder, G. C., J. Biol. Chem., 1923-24, lviii, 617. Observations on the Inorganic Bases and Phosphates in Relation to the Protein of Blood and Other Body Fluids in Bright's Disease, and in Heart Failure.

18. Hastings, A. B., Murray, C. D., and Sendroy, J., Jr., J. Biol. Chem., 1926-27, lxxi, 723. Studies of the Solubility of Calcium Salts. I. The Solubility of Calcium Carbonate in Salt Solutions and Biological Fluids.

19. Peters, J. P., and Eiserson, L., J. Biol. Chem., 1929, lxxxiv, 155. The Influence of Protein and Inorganic Phosphorus on Serum Calcium.

20. Stewart, C. P., and Haldane, J. B. S., Biochem. J., 1924, xviii, 855. Experimental Alterations in the Calcium Content of Human Serum and Urine. 
21. Haldane, J. B. S., Wigglesworth, V. B., and Woodrow, C. E., Proc. Roy. Soc., Series B., 1924, xcvi, 1. The Effect of Reaction Changes on Human Inorganic Metabolism.

22. Salvesen, H. A., Hastings, A. B., and McIntosh, J. F., J. Biol. Chem., 1924, $\mathrm{lx}, 327$. The Effect of the Administration of Calcium Salts on the Inorganic Composition of the Blood.

23. Fiske, C.H., and Subbarow, Y., J. Biol. Chem., 1925, 1xvi, 375. The Colorimetric Determination of Phosphorus.

24. Fiske, C. H., Unpublished Method for Calcium, first described in paper by Hamilton, B., J. Biol. Chem. 1925, lxv, 101.

25. Farquharson, R. F., Salter, W., and Aub, J. C., J. Clin. Invest., 1931, x, 251. Studies of Calcium and Phosphorus Metabolism. XIII. The Effect of Ingestion of Phosphorus on the Excretion of Calcium.

26. Farquharson, R. F., Salter, W. T., Tibbetts, D. M., and Aub, J. C., J. Clin. Invest., 1931, x, 221. Studies of Calcium and Phosphorus Metabolism. XII. The Effect of the Ingestion of Acid-Producing Substances.

27. Wigglesworth, V. B., Woodrow, C. E., Smith, W., and Winter, L. B., J. Physiol., 1922-23, lvii, 447. On the Effect of Insulin on Blood Phosphate.

28. Harrop, G. A., and Benedict, E. M., J. Biol. Chem., 1924, lix, 683. The Participation of Inorganic Substances in Carbohydrate Metabolism.

29. Blatherwick, N. R., Bell, M., and Hill, E., J. Biol. Chem., 1924, Ixi, 241. Some Effects of Insulin on the Carbohydrate and Phosphorus Metabolism of Normal Individuals.

30. Briggs, A. P., Koechig, I., Doisy, E. A., and Weber, C. J., J. Biol. Chem., 1923-24, lviii, 721. Some Changes in the Composition of the Blood Due to the Injection of Insulin.

31. Brougher, J. C., Am. J. Physiol., 1927, 1xxx, 411. Blood Calcium as Affected by Insulin.

32. Davies, D. T., Dickens, F., and Dodds, E. C., Biochem. J., 1926, xx, 695. Observations on the Preparation, Properties and Source of the Parathyroid Hormone.

33. Ellsworth, R., J. Clin. Invest., 1930, viii, 139. Secondary Alterations in Total Serum Calcium After Administration of Glucose and Insulin.

34. Schulz, F., Ann. Int. Med., 1930, iii, 667. Phosphorus in the Blood and Urine; A Study of the Excretion and Retention of Phosphorus in a Normal Subject and in Patients with Renal Disease. 